\title{
Government Involvement in Corporate Debt Restructuring: Case Studies from the Great Recession
}

\author{
David A. Grigorian, Faezeh Raei \\ International Monetary Fund, Washington DC, USA \\ Email: dgrigorian@imf.org, frari@imf.org
}

Received December 2, 2012; revised January 3, 2013; accepted February 5, 2013

\begin{abstract}
The paper examines recent episodes of government involvement in corporate debt restructurings. It argues that corporate debt restructuring is an important step toward recovery from a financial crisis. Due to interlinkages between the balance sheets of corporations and the financial sector, without an effective corporate debt restructuring, bank lending is likely to remain constrained. We then discuss the rationale for, and modalities of, the state intervention in corporate debt workouts through reviewing six countries with large scale corporate debt workouts. Case studies reveal that the costs of corporate sector rescue are significant and in several cases on par with the costs of financial sector support. The paper sheds light on the importance of contingent liabilities and associated risks to government balance sheet from the corporate debt side and draws conclusions that point to the need for improved surveillance and governance going forward.
\end{abstract}

Keywords: Corporate Debt Restructuring; Contingent Liabilities; Quasi-Sovereign Risk

\section{Introduction}

Pressures from the global economic crisis and resulting tighter credit conditions have given rise to corporate debt problems across the world. High debt service costs, un-hedged foreign currency risk, and roll-over problems have threatened the solvency of corporations, including some systemically important ones, in a number of countries.

The widespread corporate debt problems have posed complications on a number of dimensions. First of all, debt problems have created real risks of disruption of activity/output as stressed corporates have difficulties meeting their working capital needs to secure production. This in some cases led to weaker capacity to service existing debt and further deteriorated the corporations' balance sheet. Second, the slowdown of activity contributed to unemployment and related social pressures. Third, corporate debt problems and the resulting increase in non-performing loans (NPLs) endanger the already weakened banking system and further reduced the ability of banks to extend credit, thus slowing down the recovery. Debt over-hang thus became self-perpetuating as corporations are unable to deleverage by retaining earning or issuing equity because of recession, but recession is being prolonged by the high level of debt ${ }^{1}$. Forth, govern-

${ }^{1}[1]$ Finds a two-way causality between bank and corporate distress and to significant global macroeconomic and financial spillovers from either type of distress when it originates in a systemically important economy. ment rescue efforts of embattled corporates typically entail direct fiscal costs and-to the extent the experience past crises is of any guidance-may have increased the contingent risk in the future due to moral hazard ${ }^{2}$. The resolution of corporate debt problems thus became an important part of the recovery strategies across a range of countries affected by the crisis.

The condition of the corporate balance sheet turned out to be particularly relevant for the recovery of the banking system. Recent data show that non-performing loans of household and corporate sectors take on an increasing trend in the years following the start of the crisis. In some countries and regions, nonperforming loans doubled in 2009 compared to 2008 (Figure 1, Panels 2 and 3). As a result, banking asset write-downs continue to be significant and growing in 2010 compared to 2009 (Figure 1, Panel 1). While the data do not allow us to distinguish between household and corporate NPLs for all countries and regions, reporting from US, UK, and Euro Area shows that as much as 17 to 23 percent of writedowns in 2007-2010 comprises commercial mortgage and corporate loans.

Given the importance of interlinkages between corporate debt problems on the one hand and the recovery of financial system and overall economy on the other hand, several governments have embarked on measures to help facilitate the process of corporate debt resolution. The

${ }^{2}$ See $[2,3]$ for a description of cross-country widespread corporate debt restructuring in Latin America and Asian crisis. 

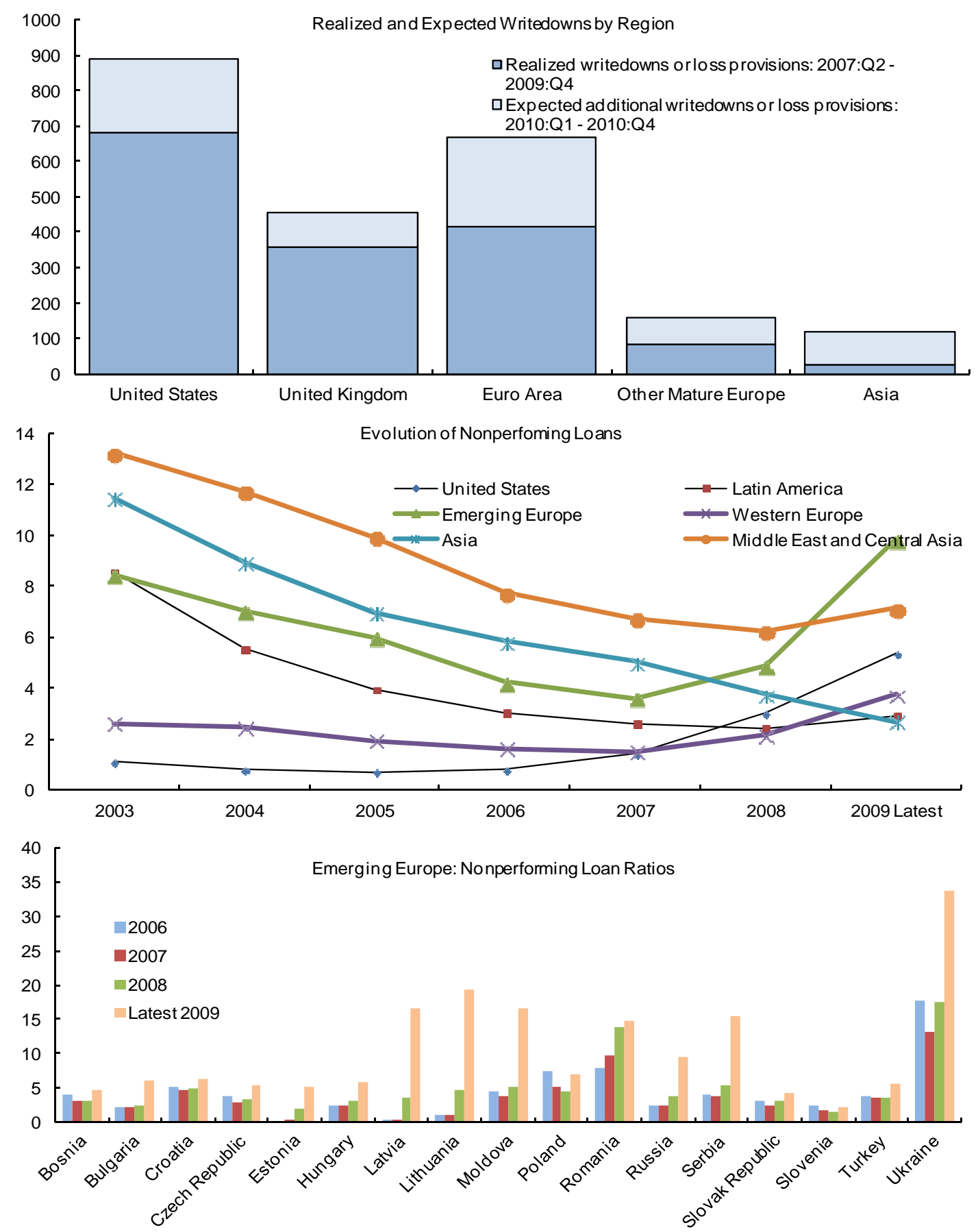

Figure 1. Evolution of nonperforming loans. Source: Global financial stability report, April 2010 and country sources.

paper surveys the most prominent episodes of corporate debt restructuring associated with the recent crisis, namely those in Latvia, Russia, Spain, UAE, Ukraine, and the US and provides a comparison of modalities of government intervention and the underlying patterns. These countries differed in their approaches to handling the corporate debt distress and have employed both direct (i.e., budget-to-corporates) as well as the indirect (i.e., budget-to-banks-to-corporates) assistance methods to ad- dressing them. Those that did not have previous experience with handling large-scale corporate distress also embarked on the reform of the legal, tax, and regulatory foundations for speedy and orderly restructuring. The scale of government interventions adopted in response to corporate debt problems mainly reflected the differences in the scope of the debt problem, the nature of the corporations involved, and the type of the debt observed across countries. 
However, like any public intervention, these ones raised questions regarding their rationale as well as their modalities, costs, and benefits. In some cases, (the size of) government assistance packages have contributed to heightened sovereign risk and brought debt sustainability considerations forward. In doing so, these interventions used resources that otherwise had ample use during the crisis times and made governments weaker positioned to handle other crisis-related eventualities in the future. They may have also fostered moral hazard by essentially rewarding both borrowers and creditors for job poorly done, with potential implications for pricing quasi-sovereign risk in the future. All in all, challenges posed by corporate distress to governments were formidable, with the choice and modality of such intervention having significant implications for government risks and costs. In some countries, the latter often rivaled the costs of financial sector bailouts, highlighting the importance of adequate monitoring of contingent risk as well as of liability management in general.

While wide-scale corporate debt restructuring as seen during the Asian crisis has so far been avoided, this may not be over yet. Corporate debt problems tend to lag a crisis by one to two years as the effects of crisis trickle down the economy and protracted recession dries up corporation's ability to service debt. This might be the case in countries where the rate of NPL growth is accelerating to alarming levels making further state interventions likely down the road.

The paper is organized as follows. Section 2 discusses the rationale, general principles, and modalities of government intervention and offers an in depth discussion on the role of the financial sector and asset management companies in corporate debt workout. Considerations for financial system are discussed and lessons from restructuring in previous crisis are drawn. Section 3 offers a detailed discussion on studies of restructuring efforts in the above countries. Inferences are drawn based on the cases discussed but also against the background information from previous crisis. Finally, Section 4 concludes and provides a summary of case studies.

\section{Rationale for and Modalities of Corporate Debt Restructuring}

\subsection{General Considerations}

The objective of corporate debt restructuring is a timely and orderly restructuring of corporate liabilities with a view to restoring the corporations' operation and financial viability. To achieve these objectives, debt restructuring can take the form of a rescheduling of repayment, a change in interest rate, a change in the currency denomination of the debt, or reducing the principal of the debt. Accordingly, it may or may not imply a change in the present value of debt but often provides some much-needed breathing room for corporations (such as, flow rescheduling). To the extent that a restructuring results in a reduction of NPV of debt, this poses risks to the creditors. Depending on the size of the reduction, restructuring corporate debt could potentially lead to a breach of regulatory norms by the creditor, its bankruptcy, and/or a push to merge.

In cases where the number of troubled corporations is small, their potential macroeconomic importance is limited, and the financial system is sound, the rationale for government's involvement in corporate debt workouts is weak. In contrast, when the corporate debt problems are widespread, with potentially sizable macroeconomic consequences, and market failures inhibit debt workouts on the required scale, a comprehensive approach involving government would be warranted ${ }^{3}$. In these cases, however, the framework of such involvement needs to be carefully defined. That choice typically involves weighing the costs of intervention against the need for a speedy restructuring. The costs are not limited to the direct financial ones, and include indirect economic costs that could eventually appear from both action and inaction of the government.

Governments' specific role in an effective corporate debt restructuring process typically includes provision of: 1) appropriate legal foundations, 2) mediation and incentives for out-of-court resolutions, 3) direct financing, and 4) facilitating restructuring often by setting up Asset Management Companies. We discuss the foundations of, and the rationale for, these types of interventions in the remainder of this section.

Large scale debt workouts may require an overhaul of the legal framework and corresponding enforcement mechanisms. A workable insolvency law is essential for giving the sides incentives to cooperate. The government has a role to introduce or amend such a law to spur and start debt restructuring if the current framework is deficient. During the Asian crisis, some countries adopted frameworks to facilitate and encourage corporate restructuring that includes using new bankruptcy provisions as an incentive for creditors and debtors to negotiate.

Government's involvement as a mediator is normally warranted if there are market failures inhibiting banks from effectively leading debt restructuring, sharing information, and forming a common strategy. Such factors include lack of cooperation and excessive negotiating power by debtors or creditors. Experience in several countries demonstrates that the government can play a constructive, yet informal role in facilitating an orderly

${ }^{3}[2]$ and [4] discuss various bottlenecks and market failures that inhibit debt restructuring. For example, court capacity to handle large number of cases can be limited even in efficient legal systems. Attrition problems can plague voluntary loan workouts, with delays that are optimal for the individual negotiators but not for the economy as a whole. 
workout of debts (the "London approach") 4

Direct government financial assistance to facilitate debt restructuring is generally observed in cases where debt problems are pervasive and impose negative externalities on the economy. The incentives may include compensation to creditors for lengthening the maturities or providing guarantees for corporate loans. This approach was common in Latin American restructurings in the $1980 s^{5}$. Sometimes, such support also includes direct lending to companies that are viable but are unable to access markets on their own. In addition to direct assistance to corporations, governments may provide indirect support to the corporate sector via assistance with bank recapitalization and liquidity provision. This approach is often used when corporate debt problems cause deterioration in bank balance sheets and affect the provision of credit, and reduce banks' capacity for debt restructuring. Cases include Chile (1981-1983); Mexico (1995-1997); Poland (1993); and more recently Russia, Ukraine, and Dubai.

Asset Management Companies (AMCs) have been used to spearhead the restructuring of corporate debt with a view to maximizing recovery of viable firms and supporting the viability of the banking sector. These companies, which could be government-sponsored, private, and intermediate, can buy bad loans and provide equity to banks and corporations. The debt taken by such corporations can be converted to equity and eventually sold to public. These corporations enjoy economies of scale in debt restructuring, facilitate the debtor-creditor negotiation and can develop secondary debt markets. They were prevalent in varying degrees during the Asian crisis (e.g., Indonesia, Malaysia, Korea, and Thailand), and also in Mexico during 1995-1997.

Country experiences with wide-scale corporate debt restructuring in the past have been mixed and have involved lengthy and difficult processes ${ }^{6}$. While outcomes varied by country, the past experience indicates that a properly designed strategy would generally make the best use of limited fiscal resources, target interventions where needed most, leverage market-based solutions and private resources, bolster credit enforcement and insolvency laws, and preserve credit culture.

\footnotetext{
${ }^{4}$ The "London Approach" refers to the approach taken by Bank of England during the UK recession of 1970, encouraging creditors and debtors to adopt a coordinated approach to the following principles: 1) minimizing losses to creditors; 2) avoiding liquidation of viable debtors and 3) continuing financial support to viable debtors in out-of-court restructuring agreements. The approach is not enshrined formally to avoid excess legality and maintain flexibility and adoptability. Bank of England played the role of a broker in resolving disputes between the participating creditors. The approach was implemented in over 160 cases during 1987-1997 in UK Modifications of this approach have been implemented during the Asian crisis (see [2], and [5]).

${ }^{5}$ For example, Chile and Mexico provided incentives/subsidies for banks to restructure and convert dollar-denominated debt into longer maturity local currency debt [2].

${ }^{6}$ See [3] and [5] for example.
}

Tailoring a corporate debt restructuring strategy to individual country circumstances is a complex process involving attention to a number of key factors: 1) policy coordination; 2) analysis of data to assess the dimensions of the debt problem; 3) reform of the legal and institutional framework for enforcement of credit, particularly the corporate insolvency law; 4) facilitation of out-ofcourt restructurings; 5) facilitation of voluntary standstills; 6) identifying the rationale for government financing; 7) consideration of different treatment for SMEs; and 8) coordination with financial sector restructuring, particularly with respect to banks ${ }^{7}$.

\subsection{The Role of the Banking Sector}

Despite the fact that typically a variety of creditor types are involved in corporate sector debt restructuring, rehabilitation of the banking sector remains a key priority for a corporate debt crisis containment and resolution. While a corporate debt workout is in the longer-term interest of banks, they must first support their own viability and establish loss absorption capacity prior to engaging in corporate debt workouts. The drain on bank capital due to the first wave of a crisis, coupled with the existence of a number of creditors that require some degree of debt restructuring, may lead to curtailment in lending (to both viable and non-viable firms) thus exacerbating the impact of the crisis ${ }^{8}$. Weaknesses in the banking sector could prolong the restructuring of the corporate debt: the weaker the banks are the less likely that the corporations will negotiate to restructure their distressed debt as they may expect to be better off negotiating with failed rather than operating banks. This may in part explain the appearance of strategic corporate loan defaulters in time of banking distress.

Banks tend to prefer a market-based system of debt restructuring in order to avoid costly court-based bankruptcy procedures ${ }^{9}$. However, in a systemic crisis, the incentives of the banks alone are not always sufficient to secure a speedy and efficient restructuring of corporate debt. Coordination failures and externalities may inhibit progress. An example of a failure to achieve an efficient outcome is related to the degree of concentration of ownership claims. Dispersed claim holding by the banks makes it harder for the borrower to negotiate better terms and may lead to asset grabbing and creditor runs. Concentrated claim holding, on the other hand, may result in the bank losing interest in the going-concern value of the corporate debtor and liquidating it prematurely in order

\footnotetext{
${ }^{7}[4]$ provides an in depth discussion of these elements.

${ }^{8}[6]$ shows evidence of this for a large sample of debt workouts between UK banks and corporations. For similar lessons from the Mexican and Asian crisis experience, see also $[7,8]$.

${ }^{9}$ Costs associated with diverting management time and effort away from running the firm, among other agency costs related to bankruptcy, have been highlighted by Jensen and Meckling (1976).
} 
to ensure full recovery of the value of the loan. In addition, corporate debt restructuring could be more challenging in cases with material presence of non-bank financial institutions, such as hedge funds, with differing incentives from those of banks that could complicate the coordination of creditor action. Government's intervention in securing the availability of resources and the right set of institutional arrangements for negotiating parties is, therefore, commonly required.

Bank recapitalization, involving some use of public funds, has been a common feature to restore capital depleted by widespread corporate defaults and to allow banks to take longer term rational decisions on corporate debt restructuring ${ }^{10}$. In some cases, the injection of public funds was made conditional upon some degree of banks' progress in corporate debt restructuring [9]. This type of conditionality could be considered in general, provided that their introduction does not delay bank restructuring.

Some additional government measures to promote bank restructuring and support the role of banks in corporate debt restructuring include:

- Government support for setting up specialized advisory and investment banking services to facilitate negotiations between banks and corporations and minimize coordination problems ${ }^{11}$;

- Offering tax and other financial incentives to banks (including to AMCs) to expedite out-of-court debt restructuring $^{12}$;

- Enhance transparency (by using supervisory powers to require banks to disclose claims to relevant negotiating parties) to speed up debt negotiations;

- Ensuring strict enforcement of existing NPL classification and other regulatory guidelines to strengthen the banks' incentives to participate in debt restructuring;

- Defining a clear and concise timetable for various stages of the debt workout process. To achieve maximum participation from both sides and minimum disruption along the way, supervisory penalties for noncompliance could be imposed.

In the context of the current crisis, the cross-border dimensions of bank operations may complicate the design and implementation of government intervention.

\footnotetext{
${ }^{10}$ All nine corporate debt restructuring studied by [2] included some government-sponsored bank recapitalization: Chile, 1981; Hungary, 1991; Indonesia, 1997, Korea, 1997; Malaysia, 1997; Mexico, 1981; Mexico, 1995; Poland, 1993; and Thailand, 1997. Indecisive action in the recognition of losses and recapitalization of banks has been a factor cited as prolonging the debt adjustment process in Japan during the 1990s.

${ }^{11}$ An example is the Corporate Debt Restructuring Committee (CDRAC in Thailand. In principle, such government support could be through establishing government advisory agencies or providing financial support to present or new-entrant private financial institutions offering specialized investment banking services.

${ }^{12}$ Attaining a low-interest rate environment could have similar implications to providing government-subsidized loans to banks to facilitate the debt workout.
}

Capacity to exercise regulatory suasion over foreign banks and their affiliates may be limited. Where public financial support to the banking system is related to debt restructuring programs relieving the industrial or household sectors in one country, sharing these costs among governments can present a challenge. Although a greater share of foreign-owned banks may in effect result in a greater share of the adjustment burden being borne by foreign creditors, strategies that intentionally target foreign creditors should be avoided in view of the negative effects on access to international credit and investment, which could be needed to sustain economic recovery. However, the presence of foreign participants in the banking system can in certain circumstances support a corporate debt restructuring by enhancing financial resources and technical expertise that can be put into the debt restructuring effort ${ }^{13}$.

\section{Selected Recent Debt Restructuring Cases}

This section reviews corporate debt restructuring in countries mentioned above in the aftermath of the recent financial crisis. It should be noted that developments in these cases are still unfolding, making the overall assessment conditional upon the final outcome.

\subsection{Russian Federation}

\subsubsection{Background}

In the wake of the global financial crisis, the Russian economy was hit hard by dual shocks [9]. The two key external drivers of Russia's prolonged boom-rapidly rising oil prices and massive capital inflows - sharply reversed in summer 2008 triggering a sharp contraction in domestic demand. Investment plummeted, shattering the nexus of high growth in investment, productivity, and real wages that had powered consumption and the economic boom, bringing real GDP sharply down in 2009. Although rising oil prices and renewed capital inflows have provided some support to the ruble in 2010, the economy remains weak.

Troubles for the corporate sector began in the second half of 2008, when declining oil prices reversed the exchange rate expectations and led to ruble depreciation. This, in turn, brought about a massive drive by the highly indebted corporate sector (which had accumulated large sums of foreign currency debt during the boom years) to hedge foreign currency exposure ${ }^{14}$. Capital outflows,

\footnotetext{
${ }^{13}$ In this respect, the presence of foreign banks in the Latvian banking sector appears to support the relative prospects of corporate debt restructuring in that country.

${ }^{14}$ The amount of corporate debt had more than doubled reaching a peak of $\$ 276$ billion dollars in September 2008 in two years (See Figure 2). Throughout this growth, the share of foreign currency denominated debt had consistently remained high at around 80 percent of total debt. This made the firms highly vulnerable to large swings in exchange rate.
} 
which reached \$131 billion in the fourth quarter, took various forms including shifts from ruble to foreign currency deposits and foreign debt repayments by the nonbank corporate sector.

As a result of higher unemployment and weaker demand, many companies have posted losses and faced difficulties in servicing their debt. Corporate NPLs have doubled between September 2008 and March 2009 and are expected to continue to grow (Figure 2). Refinancing became a major obstacle for the corporations' liability management.

\subsubsection{Policy Response}

In the initial phase of the crisis, the authorities focused on containing the crisis through stabilizing the banking sector and maintaining exchange rate stability. To
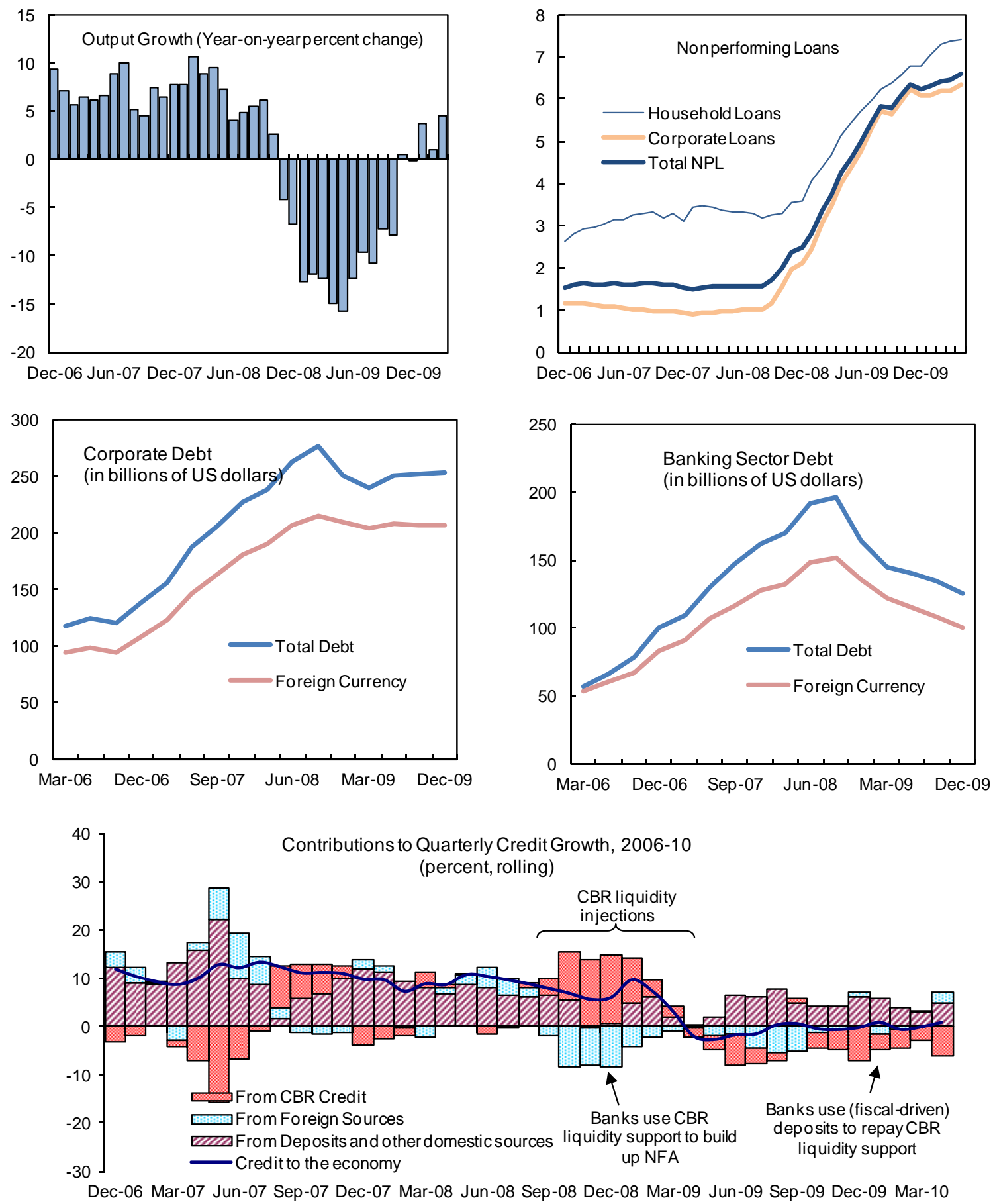

Figure 2. Russian federation: credit and NPLs. Source: Central Bank of Russia, Rosstat; and IMF staff calculations. 
achieve these goals, the Central Bank of Russia (CBR) intervened heavily to manage the ruble's decline ${ }^{15}$. Moreover, CBR and Ministry of Finance introduced a range of liquidity, asset purchase, and recapitalization schemes to the banking sector to provide liquidity and cushion the reduced access to external markets. The support measures have stabilized the banking system in the early stages of the crisis. However, as the output continued to drop, NPLs in the household and corporate sectors grew increasingly. Responding to growing NPLs, CBR introduced forbearance by easing loan classification and provisioning requirements in order to boost banks abilities to absorb losses, restructure loans, and extend credit.

The government's plans to address corporate sector problems have been multifaceted and evolved in the course of the crisis. At the outset, the government set up facilities to help select large companies who had become unable to rollover their large external debts. These companies (both state- and privately-owned) were deemed strategically important for the economy and employment. Later on, the government shifted to a more comprehensive approach to provide support for all companies by providing loans, tax cuts, and subsidies. In addition, corporate law was amended to encourage debt restructuring.

In October 2008, with the enactment of the federal law "On Additional Measures for Supporting the Financial System of the Russian Federation”, the state-owned VneshEconomBank (VEB) became a key instrument in the governments' crisis management plans via two major lines. One was to extend direct foreign currency loans to strategic companies that had difficulty in servicing their foreign currency debt. The other was to provide banks with unsecured subordinated loans in order to boost the capital of banks against increasing NPLs as well as provide them with liquidity.

Drawing from CBR funds deposited at VEB, the CBR extended foreign currency loans to companies for servicing foreign currency debt, which they obtained from foreign financial institutions prior to September 25, 2008. The loans ranged from $\$ 100$ million to $\$ 4.5$ billion carrying an interest rate of at least at $\mathrm{LIBOR}+5$ percent. By end-2008, the volume of the loans extended for refinancing indebtedness owed to foreign creditors reached $\$ 9.8$ billion, with the total reaching $\$ 14.3$ billion by $2010^{16}$.

The first tranches of VEB loans under the government support scheme were extended to large and strategic corporations that faced difficulty in accessing credit and refinancing their debt. For instance, $\$ 4.5$ billion was al-

\footnotetext{
${ }^{15} \mathrm{CBR}$ interventions resulted in foreign reserves dropping by more than US \$200bn between their peak in August 2008 and early-2009. The CBR backed this up with interest rate increases in early February 2009.

${ }^{16}$ See http://www.veb.ru/en/sup/supref/_and VEB 2008 Annual Report.
}

located to the aluminum giant Rusal, secured against a 25 percent stake in another metallurgical giant, Norilsk Nickel; and Alfa Group received \$2 billion against its 44 percent stake in mobile phone operator Vimpelcom. Other companies that are reported to have obtained loans from VEB include the state oil giant Rosneft (\$800 million), the partially state-owned car maker AvtoVaz, and privately-owned property group PIK (\$262 million).

The loans for refinancing debts have kept the highly indebted large corporations afloat and provided them with a chance to work towards restructuring their remaining debt. In the case of Rusal, the VEB loans saved the firm from asset sales and paved the way for debt restructuring and later an IPO. This has also been the case for AvtoVaz and PIK group (see Table 1 for details). In some cases the extension of loans was made conditional on a business plan restructuring and/or further debt restructuring.

In addition to providing assistance to large companies, the government shifted to a more comprehensive approach to supporting corporate sector after the initial phase of crisis was over. This included reduction in early-2009 of the corporate tax rate from 24 percent to 20 percent and the tax rate on small enterprises from 15 percent to 5 percent. Moreover, SME loan program schemes have been set up and by end April 2010; \$1 billion of such loans have been disbursed by VEB. Finally, insolvency legislation was amended (twice, in 2008 and again in 2009), inter alia to encourage reorganization and use of insolvency procedures by the debtor and unsecured creditors ${ }^{17}$.

The resources for these operations were drawn from the National Wealth Fund (NWF) as well as the CBR reserves, both by and large a product of oil export revenues of the recent past. Specifically, VEB received $\$ 50$ billion of CBR reserves for on-lending, with more funds from the NWF being placed on term deposit with $\mathrm{VEB}^{18}$.

\subsection{Spain: Property Development Sector}

\subsubsection{Background}

After a decade of rising property values and strong growth in the real estate sector, Spain's property boom started unwinding in 2008. The construction boom was by and large funded by debt. By mid-2008, Spanish

\footnotetext{
${ }^{17}$ The changes include the Law No. 296-FZ amending Federal Law No. 127-FZ "On Insolvency (Bankruptcy)" which went to effect in December 31, 2008. The Law seeks to streamline the legal framework for bankruptcy procedures with respect to Russian companies. The amendments refer inter alia to the publication of information on bankruptcy, discharge of the debtor's debts by third parties, sales of the debtor's enterprise, and activities of bankruptcy administrators. More information can be found from:

http://www.whitecase.ru/russian/index.phtml?part=update\&u_id=508

${ }^{18}$ As of April 2010, RUB 404 billion ( $\$ 14$ billion) of NWF have been used towards loans to banking system and an additional RUB 30 billion (\$1 billion) for direct loans to SMEs.
} 
Table 1. Debt restructuring in Russia.

\begin{abstract}
AvtoVAz
AvtoVAZ, Russia's largest car company has been struggling with low sales and debt problems since the beginning of the crisis. Sales fell from 730,000 cars in 2008 to an estimated 340,000 in 2009. Credit, which was used to finance the purchase of about half of all new cars, had disappeared as the Russian banks’ access to wholesale markets dried up. Unable to service its debt of approximately \$2 billion, the company's management started actions in the summer of 2009 to restructure the company's debt and offered several scenarios to its creditors. In September, there were unsuccessful talks with the company's two main creditors, Sberbank and VEB, on the possibility of debt to equity swaps to assist the company with its liquidity problems. The company continued talks about other options for restructuring the debt.

In November 2009, two of the three main shareholders, a state-owned Rostekhnologii and French car maker Renault, stepped in to help the company in a deal brokered in large measure by the Prime Minister. Renault, with a 25 percent stake in the company, announced the provision of €300 million (\$424 million) to AvtoVAZ via in-kind transfers of technology and manufacturing equipment. The Russian government agreed to increase its financial support (direct and indirect) by RUB 50 billion (\$1.67 billion). At the end of December, RUB 28 billion (\$938 million) was injected into Rostekhnologii as additional capital to be on lent to AvtoVAZ as an interest-free loan which would later be converted to a larger equity stake. The proceeds of this loan will be used to help AvtoVAZ meet its obligations to its banks.

However, the loan was to be issued only after AvtoVAZ provides the Ministry of Industry and Trade, the Ministry of Economic Development, and the Finance Ministry with an acceptable medium-term business development plan, including a prospective investment program. The conditions for the loan also included signing a mutually-acceptable debt restructuring memorandum between Rostekhnologii, AvtoVAZ, and a group of creditor banks, which includes Sberbank and VTB. An agreement was reached in April 2010.

\section{PIK Group}

In April 2009, one of Russia’s largest private real estate developing companies, asked creditors for a 4-month standstill on its debt of about RUB 40 billion (\$1.34 billion). The company was hit hard by the sharp decline of the local real estate bubble and had posted a \$1.1 billion loss in 2008 . Its key creditors-largely Russian banks-agreed to the standstill. Afterwards, the company announced its restructuring plan, aimed at replacing most of its short term debt with maturities extending over 5 years. As part of the restructuring plan, the company was to seek additional $\$ 500$ million to complete projects. It reached a restructuring agreement with key creditors in December 2009. It obtained a 12-month loan of \$262 million from VEB to help refinance its maturing debt and has obtained state-guarantees to borrow \$400 million from Sberbank.
\end{abstract}

construction companies owed approximately €156 billion to banks. Property developers had debts of approximately twice that level. Mortgages and loans to property developers accounted for over half the loan portfolio of Spanish banks ${ }^{19}$.

The crash was triggered by over-supply of residential developments, softening demand, and increased regulation of sometimes dubious developments. At the same time, the global credit crisis cut off the supply of wholesale funds to Spanish banks, restricting their lending ability, leading to higher interest rates and tighter credit conditions for banks and property developers. A large number of real estate companies, faced with shrinking revenues and tighter financial conditions, were unable to repay or refinance their debt and were forced into bankruptcy or restructuring.

The banking sector had weathered well the initial impact of the global crisis due to prudent regulation and sound supervision, but has since faced challenges. The dynamic loan-loss provisioning introduced in 2000 has provided banks with a two years worth of cushion (€24 billion). However, as NPLs increased the buffer has been running low. The weakness have been emerging also from the funding side, especially wholesale funding [11].

\subsubsection{Policy Response}

Despite a large number of corporate insolvencies, Spain's approach to corporate debt restructuring has so far been market-based. During 2008, over 1000 properties and building companies went into insolvency, a 3-fold increase compared with 2007. In 2009, Spain wit-

\footnotetext{
${ }^{19}$ See [10] for more details on housing market developments in Spain.
}

nessed some of the largest construction companies filing for bankruptcy protection and restructuring their debt (Table 2), either in-court supervised or out-of-court workouts.

Due to large number of troubled companies, Spanish government introduced amendment to the insolvency law in March 2009, to create incentives for creditors to participate in out-of-court restructuring procedures. Under the previous law, out-of-court restructurings were not common: 90 percent of insolvency procedures ended with the liquidation of the company, reflecting the failure of the insolvency law to provide a credible approach for restructuring over-indebted but viable companies. One of the issues that had created legal uncertainty was the potential rescission that may affect any restructuring agreement entered into during the period prior to the declaration of insolvency. In order for creditors to participate in an out-of-court restructuring, the government viewed it essential to protect creditors if the restructuring fails and the debtor were to become insolvent.

As highlighted in [12], the main amendments introduced were: 1) the possibility of reaching out-of-court refinancing agreements with no claw-back risk (except in case of fraud) when documented by notary deed with the support of creditors representing 60 percent of liabilities and a viability plan approved by an independent expert; 2) protection of debtors in pre-insolvency negotiation of an early creditors agreement; 3) clarification on the status of certain claims; 4) early liquidation of any of the debtor's estate; and 5) measures to reduce costs and simplify and speed up insolvency procedures.

The procedures for resolution and restructuring of the 
Table 2. Restructuring of Spain's largest real estate companies.

Metrovacesa, a publicly-traded property developer headquartered in Madrid, is Spain’s largest real estate company. In February 2009, following a $€ 738$ million loss in the previous year, Metrovacesa's owners were forced to hand control to its creditor banks, swapping a 55 percent stake for a cancellation of $€ 2.1$ billion of loans that it could neither repay nor refinance.

Inmobiliaria Colonial, a publicly traded and second largest property firm in Spain, was in the process of restructuring €4.9 billion in debt by using an out-of-court workout mechanism. As part of the workout, in December 2009, two private-equity groups-Colony Capital Partners and Orion Capital Managers - agreed to purchase Colonial debt from Goldman Sachs, assuming Goldman's position as the lender. Colony and Orion will convert debt with a nominal value of $€ 1$ billion into Colonial shares. It is reported that Goldman had lent as much as €1.5 billion to Colonial and sold the debt to Colony and Orion for €950 million, a substantial discount. Although few details are known (none of the parties disclosed detailed terms of the transaction), analysts believe that Colonial agreed to value the debt at 100 percent in the swap so that Colony and Orion will receive steeply discounted shares in exchange, and thereby stand to profit handsomely if Colonial shares appreciate.

Martinsa-Fadesa, a publicly traded company with $€ 4.9$ billion of debt, filed for bankruptcy protection in July 2009, making it Spain’s largest bankruptcy. Martinsa is presently working on a debt repayment plan. As of August 2009, the debt repayment plan was backed by 54 percent of its creditors, including some Spanish banks. Martinsa-Fadesa was to repay 2 percent of a syndicated loan of over $€ 5$ billion before May 2010 and 3 percent in 2011. Repayments will rise to 25 percent in 2015 and 2016.

Sacyr Vallehermoso, one of largest developers, is selling assets to raise cash for its debt repayment. It has sold its toll-road arm and is in negotiation to sell its holding in Repsol YPF, Spain's large oil company.

weak banks, particularly savings banks (with their heavy exposure to real estate) are slowly and gradually taking shape. In the initial phases of the crisis, Spain's bank assistance-in line with the common framework agreed by euro-area countries - was mostly in the form of loan guarantees and purchases of illiquid bank assets. Later with increase of NPLs and deterioration of the balance sheet in some banks, a fund for recapitalization, restructuring, and consolidation of these banks was established in June 2009. Other measures taken include: 1) raising the limit on deposit insurance from $€ 20,000$ to $€ 100,000$; 2) establishing a €30 - €50 billion fund to purchase high-quality securities issued by credit institutions; 3) providing government guarantees for credit institutions' new debt issues; and 4) creating the Fund for Ordered Bank Restructuring (on June 26, 2009) to oversee the administration of failed banks.

\subsection{Ukraine}

\subsubsection{Background}

Due to its dependence on commodity exports (e.g., steel) and external financing, the Ukrainian economy has been severely hit by the financial and economic crisis [13]. Growth in 2009 dropped by 15 percent and access to financial markets has been lost. The Ukrainian currency, hryvnya, has been one of the currencies worst affected by the global financial and economic crisis. In the six months leading to February 2009, the hryvnya had lost around 45 percent of its value against the US dollar, even with substantial central bank intervention and controls. Strong downward pressure on the hryvnya was intensified owing to demand from corporates to pay off external debt. The severe downturn has left many borrowers unable to pay their debts, especially those denominated in foreign currency.

Banking sector has been under severe strains due to tightening of external funding and rapidly increasing nonperforming loans. With higher NPLs, banks reported losses of about UAH 27 billion (3 percent of GDP) in
2009. For some banks, the capital cushions built during the 2009 have largely been eroded, and NPLs are unlikely to have reached their peaks.

In addition to banking sector, the financial situation of the state-owned energy company, Naftogaz, severely eroded in the aftermath of the crisis, resulting in disputes over payments to Russia and creating massive costs for the government. Naftogaz had posted losses for a while (including 2.6 percent of GDP in 2009), reflecting the gap between domestic and imported gas prices, lowerthan-expected sales to industry, and a rise in non-payments by utility companies. The dispute with Russia over nonpayment of imported gas costs erupted in January, causing disruptions in the supply of Russian gas to Ukraine, as well as to the Balkans and Central Europe. It was resolved after Naftogaz repaid its outstanding debt to Gazprom, and a new 10-year gas contract was signed in early-February. The contract ended Ukraine's privileged access to Russian gas and set gas prices according to market rates.

\subsubsection{Policy Response}

Facing with severe balance of payment problems, Ukraine signed an arrangement a two-year \$16.4 billion Stand-By arrangement with the IMF in November $2008^{20}$. The subsequent disbursements provided Ukraine with some relief to design and conduct a restructuring and resolution plan for banking and corporate sector problems.

Initial response in the second half of 2008 was focused on banking sector through establishment of a recapitalization unit. Later in 2009, debt problems by Naftogaz came to the fore, which resulted in government involvement and assumption of some of the liabilities. At that stage, steps were also taken to improve regulatory environment for corporate debt restructuring.

\footnotetext{
${ }^{20}$ The program later went off track in late 2009 and did not fully disburse due to disagreements over fiscal issues. A new 29months program (\$15.1 billion) was agreed upon in August 2010.
} 
The strained and undercapitalized banking sector was an impediment for corporate debt restructuring and required prompt action. The recapitalization process intiated by the National Bank of Ukraine (NBU) included a diagnostic phase to identify capital deficiencies, recapitalization plans, and resolution mechanisms for banks unable to meet the capital requirements. The diagnostic study of systemic banks (covering 38 banks accounting for 85 percent of total assets) revealed large capital deficiencies. Subsequently, in December 2008, two stateowned banks have been recapitalized, through an injection of UAH 14.4 billion ( $\$ 1.8$ billion) in line with the diagnostic study results. For the private banks, the results revealed a capital deficiency of UAH 30.5 billion ( $\$ 4$ billion or 3 percent of GDP). The shareholders of the private banks were required to raise additional capital. While most private banks have been able to raise the required capital, some are and will be partially taken over by the government adding to the fiscal burden of the crisis management.

To increase incentives for corporate debt restructuring, in addition to the overhaul of the banking sector, the authorities embarked on reforms to facilitate the voluntary out-of-court rehabilitation. The court supervised restructuring processes are generally long, costly, and result in unnecessary liquidations of solvent firms. With the number of insolvency cases rising during the crisis, there was a need to improve the insolvency law to facilitate out-ofcourt workouts $^{21}$. The new amendments and structural reforms included establishing a fast track court approval for out of court restructuring agreements and streamline liquidation procedures.

However, the saga with Naftogaz was the highlight of corporate debt problems in Ukraine. Years of subsidized gas sales and recent high oil import prices, deteriorated the finances of the company and forced the company to seek restructuring of its debt. With the involvement of government, the liabilities of Naftogaz were swapped with government guaranteed bonds worth $\$ 1.6$ billion, or 2.7 percent of GDP (Table 3). This would be comparable to recapitalization costs of the banking system that were estimated to be about 3 percent of GDP in 2009 and an expected 2.4 percent of GDP in 2010 [13 $]^{22}$.

\footnotetext{
${ }^{21}$ In Ukraine, the court procedure for bankruptcy shows a very low rate of creditors' claim payout (9 percent on average against 28 percent in the Eastern Europe and Central Asia). Bankruptcy-related procedures absorb 42 percent of the value of the business and restoration of debtor's solvency and/or declaring him a bankrupt lasts 3 years on average and lead to liquidation of 90 percent of companies involved. See "Bankruptcy System in Ukraine: Through the Past to the Future," Foundation for Effective Governance. Available at: http://www.feg.org.ua/en/news/foundation_press/164.html

${ }^{22}$ Bank recapitalization so far has been by and large in the form of recapitalization bonds. They were issued to the state-owned UkreximBank (UAH 4 billion, at 9 percent interest) and state-owned OschadBank (Savings Bank) (UAH 10.4 billion, at 12 percent interest) and subsequently repoed at the NBU for liquidity.
}

\subsection{Latvia}

\subsubsection{Background}

Latvia underwent a severe economic contraction. Real GDP declined by 4 percent in 2008 and 18 percent in 2009, with the recovery expected to start in late-2010 and into 2011. Prior to that, in 2000-2007, Latvia grew at annual rate of 9 percent, making it one of the fastest growing economies not only in Europe but in the world. The growth was accompanied by huge reliance on private capital inflows. In 2006 and 2007, the current account deficit grew to more than 20 percent of GDP. Between 2005 and 2008, wages doubled. Much of the demand was channeled into property, causing a bubble in real estate prices.

Latvian private sector was heavily indebted and large FX exposures existed both in the banking and corporate sector. The largest share of debt is attributable to the banking system. The corporate sector has also a high level of debt, with the households being considerably less indebted. The same pecking order holds for the three sector's share of foreign denominated debt. Majority of banks debt and more than one third of corporate debt are denominated in foreign currency. Households' debt is mainly in the form of residential mortgages.

Corporations and households faced a significant debt distress. The decline in economic activity has significantly reduced the ability of private sector to repay debt. NPLs have increased sharply. Between the end-2008 to October 2009, the loans overdue more than 90 days increased from 3.6 to 15 percent of total loans, almost equally distributed between the household and corporate sector.

Banks are restructuring many of these loans (by offering borrowers grace periods on principal payments, capitalization of interest and extending loan maturities) and this has created losses of about 5 percent of GDP. While easing the borrowers' cash constraints, the methods applied do not reduce the debt overhang. Banks may be reluctant to write off principal because of the impact on their capital. For residential loans that cannot be restructured banks have started to lease back properties to the previous owners, rather than selling collateral in the current environment.

\subsubsection{Policy Response}

To date, debt restructuring in Latvia has predominantly taken place in the financial sector with several bank recapitalization plans. These, however, came at a significant cost, estimated at 4 percent of GDP in 2008 and estimated 7 - 8 percent of GDP each year until 2012 [14]. With the continued rise of NPLs, banking system remains fragile and its stability depends upon the continued involvement of the largest foreign banks that account for 
Table 3. Ukraine's naftogaz.

The finances of the state-owned gas company worsened in recent years due to higher imported gas prices from Russia and subsidized domestic gas sales. Unable to pay the principal of a $\$ 500$ million bond due on September 30, 2009, Naftogaz announced a desire to restructure the debt one week before the due date. The announcement offered to swap its $\$ 500$ million unguaranteed debt maturing in a week for fresh sovereign-guaranteed bonds with a higher 9.5 per cent coupon and five-year maturity. Investors were given a deadline of October 19 to accept or reject the offer, with modest extra incentives offered to bondholders who tendered their bonds before October 8. At the same time, Naftogaz started negotiations with its bilateral creditors to convert their loans into the new Eurobond.

On October 19, the company announced that 93 percent of the bondholders had agreed to the exchange and that the remaining bondholders would be brought in at a special bondholders meeting, as provided for in the collective action clauses of the old bond. On November 5, Naftogaz announced that it had completed the restructuring not only with its bondholders but with all its bilateral lenders as well, with the old debt being converted into a new \$1.6 billion government guaranteed Eurobond, maturing in 2014 and with an annual coupon of 9.5 percent. The company itself was restructured from a state-owned entity into a public joint-stock company with the shares owned by the government.

In light of the large fiscal risks to the government balance sheet, several steps were taken towards streamlining and operational restructuring of Naftogaz and safeguarding public funds. Government accounts have been broadened to include the deficit of Naftogaz in the government deficit and SBA targets were modified. To boost the finances of Naftogaz, authorities increased domestic gas tariff and in addition to debt guarantee, recapitalized Naftogaz through recapitalization bonds of about 2.7 percent of GDP in 2009. Finally, changes are planned in the corporate governance and accounting/reporting systems. The government commissioned an international audit firm to put in place a monitoring framework for the finances of Naftogaz and to establish a regular (monthly) and timely public reporting of key financial data.

around 55 percent of bank assets. They agreed to maintain their exposure to Latvia and are committed to providing capital and liquidity to their subsidiaries in compliance with regulatory limits.

The approach to corporate debt restructuring has been market-based with the government facilitation through improvement in the insolvency law and streamlining outof-court restructuring. Companies typically lack experience in restructuring, with inadequacies in accounting and recording standards generally hindering restructuring. In August 2009, the authorities issued guidelines for out-of-court restructuring in line with international standards. Moreover, amendments to the Insolvency Law and other credit enforcement laws have been submitted to the parliament to help streamline liquidation procedures, support rehabilitation of debtors, and facilitate speedy debt resolution. Efforts to communicate these changes to relevant stakeholders have been launched.

These initiatives will help reduce the risk of debt overhang impeding the recovery. However, with gradual increase of the non-performing loans, government involvement in corporate restructuring may be unavoidable. Moreover, companies remain highly exposed to FX risk (with gross exposure at 64 percent of GDP) with only a limited subset of cooperates naturally hedged either through FX assets or through export revenue. This creates a situation where debt servicing will become increasingly difficult, should a devaluation of national currency occur. On the other hand, if the peg holds, a combination of overvalued currency and deep and prolonged recession will also depress debt servicing capacity.

The authorities are also taking measures to address the problem of highly leveraged residential mortgages. In addition to legal reforms to expedite debt restructuring for households, they are considering a scheme to offer fiscal support for mortgage restructuring. The scheme approved in 2009, provides guarantees for loan repay- ments if banks agree to restructure mortgages ${ }^{23}$.

\subsection{Dubai}

\subsubsection{Background}

The economy of UAE, and in particular the emirate of Dubai, came under strain in 2009 as the global slowdown and credit crunch severely affected all three engines of growth of UAE and Dubai: oil sector, global trade and logistics, property developments. A further blow came when Dubai World, a government-owned enterprise with large real estate investments announced in November 2009 that it is seeking a standstill and restructuring of part of its debt. The sudden announcement put Dubai in spotlight and sent global stock markets to roil as market participants were trying to evaluate the scope and extent of the debt problem and its spillovers within and beyond the region. The uncertainties also revolved around the health of other government-related entities (GREs). There were uncertainties about the financial position of GREs, domestic banks' exposure to the distressed corporations, the legal terms of some of financial instruments used, the level of financial support to GREs from the Dubai government, as well as support from the government of Abu Dhabi and federal institutions.

Weaknesses of Dubai World were particularly prominent in its real estate activities. In the boom years, many developers ventured into speculative and risky real estate developments. GREs, in particular, benefited from a perception of government guarantees, where markets effectively treated their liabilities as quasi-sovereign, enabling them to embark on highly leveraged large-scale developments. The property boom was fueled with massive financing particularly from abroad. Between 2004

\footnotetext{
${ }^{23}$ The scheme freezes part of the loan for a period of two years, reduces monthly mortgage payments, and writes off part of the principal. To ensure that it targets those most in need, the government intends to limit the scheme's coverage to the primary residences of homeowners with mortgages up to L100,000.
} 
and 2008, credit to private sector as a ratio of non-oil GDP rose from a mere 10 percent to 140 percent. The trend in private credit boom was accompanied by an increase in foreign borrowing mostly through banks. Overall foreign borrowing as a share of non-oil GDP rose from 30 percent in 2004 to about 100 percent in 2008 exposing Dubai to refinancing and foreign exchange risks.

\subsubsection{Policy Response}

Government's initial response targeted the general economic slowdown. The central bank deployed bank liquidity support facilities and lowered interest rates. The federal government introduced a 3-year guarantee on all bank liabilities, and rolled out a large recapitalization scheme by providing AED 50 billion ( $\$ 13.6$ billion) as deposits in the banking system. Although direct exposure of banks to real estate was limited due to prudential regulations, the indirect exposure has deteriorated the overall performance of loan portfolio. The ratio of NPLs though contained by now, almost doubled from 2.5 in June 2008 to 4.6 in November 2009 [15].

The corporate restructuring so far has been limited to Dubai World and its real estate subsidiary, Nakheel. After the general initial announcement on the restructuring of $\$ 26$ billion of Dubai World debt, several healthy subsidiaries were excluded from restructuring in subsequent announcements. Currently, the restructuring of liabilities of Dubai World and Nakheel, cover some \$23.5 billion of financial debt and unannounced amount of trade/supplier credits.

Shortly after the standstill announcement on November 25, 2009, the Ruler of Dubai issued a decree to establish a special insolvency regime to facilitate the reorganization and debt restructuring of Dubai World and its subsidiaries. This deemed to be necessary, as the Dubai
World—a company established pursuant to a decree issued by the Ruler of Dubai-was not subject to any insolvency framework in the UAE, namely, the federal framework or the Dubai International Financial Centre (DIFC) framework. Moreover, it was argued that subjecting Dubai World and its subsidiaries that operate under several legal regimes within the UAE to a unified system would minimize the potential of applying different insolvency frameworks. While the DIFC insolvency regime is generally regarded to be broadly consistent with international standards, the federal insolvency framework has been rarely used and was not seen as suitable for complex multi-creditor insolvency proceedings. In addition, the decree also established a special tribunal to adjudicate disputes relating to debt restructuring of the DW Group [15].

In addition to involvement in the legal facilitation, the government appointed a chief restructuring officer to lead the process. A restructuring plan was announced in March 2010 (Table 4). Under the plan the government will provide $\$ 9.5$ billion of new funds to Dubai World and Nakheel in addition to some previous support of \$11 billion that had been used to pay interest provide working capital and repay Nakheel Sukuk (Islamic bond). According to the announcements, at least about $\$ 10$ billion of such government claims has been converted to equity. To undertake such support, the Dubai government had set up Dubai Financial Support Fund (DFSF) in early 2009 which were funded by a $\$ 20$ billion bond program. The bonds were purchased by the central bank and some Abu Dhabi banks. As such, the cost to the government for support of Dubai World would be about $\$ 20$ billion. While it remains to be seen whether the investments will generate adequate returns, it was announced that such sizable support was provided given the strategic importance of the assets in question and for sustaining Dubai's

\section{Table 4. Restructuring of Dubai world.}

The restructuring of liabilities of Dubai World and its subsidiary Nakheel covers some \$23.5 billion of financial debt and an unknown amount of trade and supplier credits. There are three types of debt (Sukuk/bond; trade credit; bilateral loans). Sukuk/bonds are expected to be paid in full. The negotiations involve the other two types. Based on few official announcements and some market commentary, it seems negotiations with trade creditors are going well but not yet finalized. Dubai World also announced reaching an agreement with the creditor committee representing banks that are owed 60 percent of bilateral debt. The deal proposal requires the agreement of the rest of the bilateral creditors. The latest developments on the Dubai World restructuring are as follows:

Sukuk/bond Holders: On May 13, Nakheel paid its $\$ 980$ million Sukuk with funds obtained from Dubai Financial Support Fund. The restructuring plan had indicated that Nakheel Sukuk 2010 and 2011 will be paid as they come due if there are enough support for the proposal.

Trade creditors: On May 14, Nakheel announced it has reached agreement with more than 50 percent of trade creditors. Under the restructuring plan, trade creditors were offered 100 percent recovery of their agreed claims with a 40 percent cash payment and 60 percent in the form of a publicly tradable security, carrying a 10 percent annual return. The 40 percent cash payment will be dispersed to trade creditors as soon as an agreement on 65 percent of the total agreed claims by trade creditors is reached.

Bilateral Loans: Banks are owed some $\$ 14.2$ billion, which Dubai World wants to reschedule into five and eight-year loans. A creditors' committee has been formed that represents major bank creditors that are owed 60 percent of the loans in value. After several months of negotiation, on May 20th, Dubai World announced reaching an agreement with the creditors' committee. Banks will be paid 1 percent interest on the loans maturing in five years. Lenders have three options under the eight-year maturities, with at least 1 percent interest and varying additional rates from 1.5 percent to 2.5 percent at maturity. Two of the options include shortfall guarantee. The options are designed to address the preference of lenders towards risk and return. The restructuring proposal requires the agreement of the rest of Dubai World's bilateral creditors. The company is expected to work in conjunction with the creditors' committee to achieve this. 
growth prospects in the future.

\subsection{United States Auto-Industry}

\subsubsection{Background}

The automotive industry in the US (and Canada) represents an example of bailout of large and strategically important corporations in the advanced economies where in normal times government ownership and financial support of corporations is rare. The US Treasury created the Automotive Industry Financial Program (AIFP) in December 2008, in order to avoid a significant disruption of the US automotive industry due to the risk that such a disruption could pose to financial market stability and the broader US economy. Due to linkages with the auto industry in Canada, the government of Canada and Ontario also provided financial support to subsidiaries of the US automakers in Canada to avoid decline in manufacturing output and employment.

The situation at the three major auto companiesGeneral Motors, Chrysler, and Ford-had been getting bleaker for some time. For a decade, the companies have been losing market share to exporters and struggling with high labor and pension costs. The financial crisis made the credit conditions for these companies very tight and eventually forced two of them into bankruptcy. Overall, sales dropped by 18 percent between 2007 and 2008, with sales of SUVs plunging about 40 percent.

In November 2008, as the economic conditions deteriorated, the big three appealed to the government for finical aid. The rationale for the appeal, and the subsequent approval of the government, was that they were too big to fail: the big three accounted for almost 50 percent of sales in the United States in 2008 and directly employed 240,000. Their failures would have had devastating impact on the overall auto industry, suppliers and the rest of the economy. According to some estimates the industry employs around 500,000 across the country and is concentrated in a few states (e.g., representing one third of all manufacturing employment in Michigan) ${ }^{24}$. The auto industry in Canada is also highly linked with that of the US Canada-US auto trade represented 20 percent of total bilateral trade in 2007. The auto industry in Canada represents 14 percent of the country's manufacturing output and employs 150,000 workers ${ }^{25}$.

\subsubsection{Policy Response}

By December 2008, GM and Chrysler had received \$6 billion and $\$ 1.5$ billion, respectively, from the Troubled Assets Relief Program (TARP). The TARP funds were directed toward the financing arms of each company. The plan was for the Treasury Department to purchase \$5

\footnotetext{
${ }^{24}$ See http://www.ustreas.gov/press/releases/tg64.htm

${ }^{25}$ See http://www.iie.com/publications/pb/pb09-4.pdf
}

billion in senior preferred equity with an 8 percent dividend from GMAC. In exchange, Treasury would receive warrants from GMAC in the form of additional preferred equity equal to 5 percent of the preferred stock purchase and would be paid a 9 percent dividend, if used.

A Task Force was formed in February 2009 to review financial and operational restructuring plans submitted by Chrysler and GM and make specific recommendations to the President regarding the restructurings and the requests for funds. Recommendations included directives on improving wage and benefit structures, and developing fuel-efficient competitive cars for the future. In March 2009, the Task Force recommended the US government to lend approximately $\$ 25$ billion in loans to the companies, including up to $\$ 5$ billion in support for automotive industry suppliers (Table 5).

The difficulties in the automotive sector have had significant impacts on government finances. Since December 2008, the US government has provided about \$81 billion in loans and equity investments to the two stressed auto manufacturers and the auto-finance company GMAC, which has not filed for bankruptcy ${ }^{26}$. The governments of Canada and Ontario have provided \$2.4 billion to support the restructuring of Chrysler Canada and have offered $\$ 9.5$ billion to support the GM bankruptcy, which has major subsidiary in Canada.

The prospects for recouping such costs are uncertain at this stage. GM returned to profitability in the first quarter of 2010 for the first time in three years, with net earnings of $\$ 865$ million. Later in April, GM announced that it had repaid the $\$ 8.1$ billion direct loan portion of $\$ 60$ billion in aid that it received from the US and Canadian governments. The repayment of the rest depends on a planned public share offering which is supposed to take place once the company's finances stabilize. Chrysler posted losses in 2009 but is expected to break even in 2010. A portion of the Chrysler loan matures in December 2011 and the balance in June 2017. It is not clear at this stage when the US and Canadian governments' investments (respectively owning 9.85 percent and 2.46 percent) will be divested.

\section{Conclusions}

The paper starts with the premise that corporate debt restructuring is an important step toward recovery from a financial crisis. Due to interlinkages between the balance sheets of corporations and the financial sector, without an effective corporate debt restructuring bank lending is likely to remain constrained. This in return will slow down corporate recovery and growth prospects. We then

\footnotetext{
${ }^{26}$ For a detailed list of loan and equity investments in the auto industry, see the table on Automotive Industry Financing Programming in latest TARP Transaction Report, available at:

http://financialstability.gov/latest/reportsanddocs.html
} 
Table 5. US car industry.

On December 10, 2008, the US House of Representatives passed the Auto Industry Financing and Restructuring Act. The bill approved \$17.4 billion in loans for GM and Chrysler in two steps: $\$ 13.4$ billion would be dispensed when enacted, with another $\$ 4$ billion for GM in February 2009. The money came from funds previously appropriated to Section 136 of the Energy Independence and Security Act, in a form of bridge loans until March 31, 2009. If the loans were to become permanent, they would have to be paid back within seven years, with a 5 percent interest rate over the first five years, and a 9 percent rate over the last two years, and they needed to be accompanied by restructuring plans towards viability. The bill also created a "car czar," who would be appointed by the President to oversee restructuring in those companies that receive funds.

The need to address the long-term structural weaknesses became more evident as the estimates of the financial needs grew and the industry's conditions eroded further with the deepening of the financial crisis. These developments ultimately forced Chrysler and GM to file for bankruptcy protection. Chrysler filed for chapter 11 bankruptcy protections on April 30, 2009. The case was completed on June 10, 2009, with the United Auto Workers' retirees' medical trust and Fiat owning major shares in the reorganized Chrysler, and the US and Canadian governments retaining small stakes. On June 1, 2009, General Motors filed for Chapter 11 bankruptcy proceedings, which were completed on July 10, with US government investing a total of US $\$ 57.6$ billion under the TARP. This resulted in the following ownership structure for GM: US Treasury (61 percent), United Auto Workers Union (17.5 percent), the Canada Development Investment Corporation (7.9 percent), the government of Ontario (3.8 percent), and the bond holders of the Motors Liquidation Company (9.8 percent). Ford, which entered the crisis in a somewhat stronger financial position, did not avail itself of government loans, but undertook an out-of-court debt restructuring and labor negotiations and raised equity through a share sale in May 2009.

discuss the rationale for, and modalities of, the state intervention in corporate debt workouts. The role of the banking sector, as a key stakeholder in corporate debt restructuring is discussed. The paper then reviews six of the most prominent country cases with sizable government-led corporate debt workouts associated with the recent crisis.

The paper sheds some light on importance of contingent liabilities and associated risk in assessing governments' fiscal stance. This is becoming critical as more observers are now in a search for adequate measures of governments' net worth and sovereign risk. The extent of governments' (implicit or explicit) contingent risk could add a more forward looking element of fiscal challenges faced by sovereigns to the conventional measures of indebtedness (e.g., debt-to-GDP, etc.). It is important to note that protracted debt problems in one particular sector of the economy, if not properly contained, could spill over to other sector due to ensuing weaknesses in the banking sector. This could then result in pressures to come up with direct fiscal spending to support the corporate sector but also to reduce tax rates on already weakening tax base.

The paper shows that perception of government guarantees to state-owned and strategic private entities could change (at times fundamentally) the behavior of both debtors and creditors and have implications for the pricing of quasi-sovereign risk. The findings also emphasize the need for contingency planning for too-big-to-fail companies-both state-and privately-owned - that have potential systemic impact. Prudent management of state-owned companies in tranquil time could help avoid counter-cyclical interventions at the time of crisis when the opportunity cost of fiscal resources is particularly high. Lessons learned from this crisis in this respect should perhaps be included in the tool box for good liability management in countries across all income groups. The specific findings of the paper are discussed in detail below Table 6.
Origins: Sources of corporate vulnerability were primarily related to problems with roll-over of debt falling due, a large portion of which was FX-denominated (e.g., Russia and Latvia). In addition, weak business practices and corporate governance in some GREs contributed to the problem: in Ukraine, Naftogaz accumulated losses due to subsidized prices and conducting quasi-fiscal activities; in Dubai, weak risk management practices contributed to over-leveraging of the balance sheets of corporations.

Rationale for intervention: A key feature of the cases reported in the paper-with the exception of Spain and Latvia - is the governments' sizable support of the large and strategic companies. Such companies-both stateand privately-owned-were seen as too big to fail, that is, important either as strategic assets or for employment and social safety net considerations.

Sequencing: Initially, most countries focused on containing the risk of financial crisis and therefore focused on recapitalizing banks. This initial wave of recapitalizations was not linked to corporate distress: corporate problems emerge with a lag. As credit tightened and corporate debt problems deepened, efforts focused on direct assistance to corporations and improving the institutional setting for debt restructuring.

Modalities of interventions: Government interventions had the following forms: 1) direct lending; 2) recapitalizations/equity injections; 3) government guarantee of liabilities; and 4) legal reform. Direct lending took place in Russia, US, and Dubai. Equity injections as well as government guarantees were used in Dubai and Ukraine. Latvian and Spanish corporates received no (direct or indirect) financial support and relied on market mechanisms. Except the US that has well-established insolvency laws, all countries in our study amended or reformed the law to facilitate (both out- and in-court) restructuring. In case of Russia, tax cuts were used to provide some relief. In some cases, government support was accompanied by demands for operational restructuring. 
Table 6. Overview of corporate debt restructuring measures in selected countries.

\begin{tabular}{|c|c|c|c|c|}
\hline & Debt restructuring measures & Government intervention & $\begin{array}{c}\text { Cost of corporate } \\
\text { support }\end{array}$ & $\begin{array}{l}\text { Cost of banking } \\
\text { sector support }\end{array}$ \\
\hline $\begin{array}{l}\text { UAE } \\
\text { (Dubai) }\end{array}$ & $\begin{array}{l}\text { Government loans to troubled } \\
\text { GREs and conversion of } \\
\text { government claims to equity. } \\
\text { Out-of-court restructuring of } \\
\text { bilateral debt through negotiations } \\
\text { with banks' creditors committee } \\
\text { and with trade creditors. } \\
\text { Bonds/Sukuk will be paid in full. }\end{array}$ & $\begin{array}{l}\text { Recapitalization of banks. } \\
\text { Introduction of a special solvency regime } \\
\text { for Dubai World. Government through } \\
\text { Financial Support Fund, provided loans } \\
\text { and funds for repayment of Sukuk and for } \\
\text { interest and operational costs. Some of the } \\
\text { funds will be converted to equity. } \\
\text { The funds are obtained through } \\
\text { government's \$20 billion bond program. }\end{array}$ & $\begin{array}{l}\$ 10 \text { - } \$ 20 \text { billion some } \\
\text { in the form of equity } \\
\text { increase and some } \\
\text { new funds. } \\
12 \text { - } 24 \text { percent of } \\
\text { Dubai GDP. }\end{array}$ & $\begin{array}{l}1 \text { percent of UAE's GDP. } \\
\text { AED } 50 \text { billion ( } \$ 13.6 \\
\text { billion) deposited in banks, } \\
\text { some converted to Tier-1 } \\
\text { capital. }\end{array}$ \\
\hline Latvia & $\begin{array}{l}\text { Developed out-of-court work-out } \\
\text { guidelines; developed and } \\
\text { implemented an information } \\
\text { strategy to raise public awareness } \\
\text { about new insolvency framework, } \\
\text { and provided training to } \\
\text { government and private } \\
\text { stakeholders about out-of-court } \\
\text { restructuring. }\end{array}$ & $\begin{array}{l}\text { Recapitalization of domestic banks. } \\
\text { No direct financial subsidy to } \\
\text { corporate sector. }\end{array}$ & & $\begin{array}{l}4 \text { - } 8 \text { percent of GDP for } \\
2008-2011 \text {. }\end{array}$ \\
\hline Russia & $\begin{array}{l}\text { Loans to large and strategically } \\
\text { important companies to repay } \\
\text { their foreign currency debt. } \\
\text { Restructuring of several } \\
\text { partially state-owned } \\
\text { corporations. }\end{array}$ & $\begin{array}{l}\text { Recapitalization of banks. Regulatory } \\
\text { forbearance of NPLs. } \\
\text { Initial response was to focus on helping } \\
\text { selected large companies via directed } \\
\text { loans and subsidies from Central Bank, } \\
\text { state banks and the state-owned VEB. } \\
\text { Focus later shifted to more comprehensive } \\
\text { approach of helping strategic companies } \\
\text { (largest employers in regions) and sectors } \\
\text { via state guarantees, procurement, tax cuts, } \\
\text { and bank recapitalization. }\end{array}$ & $\begin{array}{l}\$ 14.3 \text { billion loans to } \\
\text { large companies and } \\
\$ 1 \text { billion to SME as } \\
\text { of April } 2010 \text {. } \\
0.1 \text { percent of GDP. }\end{array}$ & $\begin{array}{l}3.1 \text { percent of GDP, } \\
\text { includes recapitalizations } \\
\text { and asset swaps/purchases. }\end{array}$ \\
\hline Spain & $\begin{array}{l}\text { Widespread debt restructurings } \\
\text { (largest developers all restructured } \\
\text { debts) undertaken on case-by-case } \\
\text { basis, all market based (i.e., no } \\
\text { government involvement.) }\end{array}$ & $\begin{array}{l}\text { Assistance provided to banking sector in } \\
\text { line with common framework agreed to } \\
\text { by euro-area countries. } \\
\text { No direct financial subsidy to corporate } \\
\text { sector. }\end{array}$ & & $\begin{array}{l}2 \text { percent of GDP, includes } \\
\text { bank recapitalization and } \\
\text { asset purchases as of } \\
\text { December } 2009 \text {. }\end{array}$ \\
\hline Ukraine & $\begin{array}{l}\text { Plan to develop a government- } \\
\text { facilitated voluntary framework } \\
\text { for restructuring corporate and } \\
\text { household debts. } \\
\text { Some progress in voluntary, } \\
\text { bank-led restructurings of } \\
\text { corporates. }\end{array}$ & $\begin{array}{l}\text { Recapitalization of banks. } \\
\text { Financial subsidy was provided to state-owned } \\
\text { gas company, Naftogaz, restructured debts } \\
\text { in September 2009: swapped } \$ 500 \text { million } \\
\text { unguaranteed debt maturing within a week } \\
\text { for fresh sovereign-guaranteed bonds with } \\
\text { higher coupon and five-year maturity; also } \\
\text { negotiated with bilateral creditors to convert } \\
\text { loans to the Eurobond). }\end{array}$ & $\begin{array}{l}2.7 \text { percent of GDP. } \\
\text { Includes the operational } \\
\text { deficit of Naftogaz } \\
\text { included in budget. } \\
\text { (Additional contingent } \\
\text { liabilities might arise } \\
\text { from the } \$ 1.6 \text { of } \\
\text { Naftogaz bonds } \\
\text { guaranteed by } \\
\text { government). }\end{array}$ & $\begin{array}{l}3 \text { percent of GDP in } 2009 \\
2.4 \text { percent of GDP in } 2010 \text {. }\end{array}$ \\
\hline $\begin{array}{l}\text { United } \\
\text { States }\end{array}$ & $\begin{array}{l}\text { Loan and equity investments } \\
\text { in GM, Chrysler, and GMAC. }\end{array}$ & $\begin{array}{l}\text { Recapitalization of banks. asset purchase } \\
\text { and debt guarantee schemes for finical sector. } \\
\text { Providing loans to GM, Chrysler, and GMAC } \\
\text { and eventually acquiring stakes in these } \\
\text { companies and overseeing the restructuring } \\
\text { process. }\end{array}$ & $\begin{array}{l}\$ 81 \text { billion in loans } \\
\text { and equity investments, } \\
\text { as of June } 2010 \text {. }\end{array}$ & $\begin{array}{l}3.6 \text { percent of GDP as of } \\
\text { end } 2009 \text {, includes net } \\
\text { cost of recapitalization } \\
\text { schemes as well as asset } \\
\text { purchase and lending by } \\
\text { treasury. }\end{array}$ \\
\hline
\end{tabular}

Compared to the previous widespread corporate debt restructuring cases in Asia, the use of AMCs to take on corporate loans from the banking system has been limited.

Sources of assistance funds: In most cases with direct government support (e.g., US, Dubai, and Ukraine), funding for problem resolution came from the budget. In Russia, financing was secured through a drawdown of FX reserves and balances from the SWF.

Financial burden on the government and contin- gent liabilities: The direct financial costs of government interventions varied significantly across countries. While the fiscal and contingent costs are smaller in cases of corporate debt restructuring compared to the costs of financial sector support, they could range from zero (where no fiscal resources were deployed, see above) to 10 percent of GDP. In terms of realization of contingent risk and moral hazard, the jury may not be out yet for a while longer! However, it should be noted that contingent risks built up in the years before the crisis due to 
corporate sector debt have in some cases already translated into fiscal costs (Dubai and Ukraine).

In general, government-initiated debt restructuring and related measures have helped avoid large-scale corporate insolvencies in the sample countries. These measures provided confidence to the markets, stabilized expectations, but may have also created moral hazard. They also came at a (direct and indirect) cost to the taxpayer. These interventions weakened the governments' balance sheets as they accepted assets of questionable financial value in exchange for new resources that had ample use in crisis times. In cases where the value of government's investment depend on the performance of companies going forward, the extent of fiscal losses/gains would remain uncertain until the assistance is unwound.

Going forward, NPLs appear to be on the rise (especially in Latvia and Ukraine) and more widespread corporate debt problems could emerge. It remains to be seen whether more active government intervention would be required in these countries or whether measures already in place to address the first wave of corporate debt problems could be sufficient. At this stage, it is safe to conclude that to avoid corporate debt problems from becoming a major problem again conditions for safe and orderly debt workout should be created and maintained. While the exact figures are not available at this point, it is likely that the net costs to the governments from involvement in corporate debt workouts will be inversely related to the extent of operational restructuring imposed on the corporations after the restructuring. In cases of large state-owned enterprises, the governance and disclosure practices need to be brought up to international standards to prevent problems stemming from poor management and moral hazard from reappearing in the future.

\section{REFERENCES}

[1] Q. Chen, D. Gray, P. N’Diaye, H. Oura and N. Tamirisa, "International Transmission of Bank and Corporate Distress," IMF Working Paper 01/124, Washington DC, 2010.

http://www.imf.org/external/pubs/cat/longres.cfm?sk=238 43.0

[2] M. Stone, "Large Scale Post-Crisis Corporate Sector Restructuring," IMF Policy Discussion Paper No. 00/7, Washington DC, 2000.

[3] S. Claessens, S. Djankov and D. Klingebiel, "Financial
Restructuring in East Asia: Halfway There?” World Bank Financial Sector Discussion Paper No. 3, Washington DC, 1999.

[4] T. Laryea, "Approaches to Corporate Debt Restructuring in the Wake of Financial Crisis,” IMF Staff Position Note, SPN/10/02, Washington DC, 2010.

[5] W. Mako, "Corporate Restructuring in East Asia: Promoting Best Practices,” Finance and Development, Vol. 38, No. 1, 2001.

[6] J. Franks and O. Sussman, "Financial Distress and Bank Restructuring of Small to Medium Size UK Companies," Review of Finance, Vol. 9, No. 3, 2005, pp. 65-96. doi:10.1007/s10679-005-2988-8

[7] A. Krueger and A. Tornell, "The Role of Bank Restructuring in Recovering from Crises: Mexico 1995-1998," NBER Working Paper 7042, 1999.

[8] S. Claessens, S. Djankov and L. Lang, "Corporate Growth, Financing, and Risks in the Decade before East Asia’s Financial Crisis,” World Bank Policy Research Working Paper No. 2017, Washington DC, 1998.

[9] International Monetary Fund, "Russian Federation: 2009 Article IV Consultation,” Washington DC, 2009. http://www.imf.org/external/pubs/cat/longres.cfm?sk=231 76.0

[10] O. Aspachs-Baracons and P. Rabanal, "The Drivers of Housing Cycles in Spain,” IMF Working Paper 09/203, Washington DC, 2009.

[11] International Monetary Fund, "Spain: 2008 Article IV Consultation,” Washington DC, 2009. http://www.imf.org/external/pubs/ft/scr/2009/cr09128.pdf

[12] A. Nunez-Lagos and A. Alonso, "Spain: Urgent Changes to the Insolvency Framework," International Financial Law Review, Supplement: The 2009 Financial Crisis Guide, 2009.

http://www.iflr.com/Article/2324191/Spain-Urgent-chang es-to-the-insolvency-framework.html

[13] International Monetary Fund, "Ukraine: Second Review under the Stand-By Arrangement," IMF Staff Report, Washington DC, 2009.

http://www.imf.org/external/pubs/cat/longres.cfm?sk=232 58.0

[14] International Monetary Fund, "Republic of Latvia: Second Review under the Stand-By Arrangement," Washington DC, 2010.

http://www.imf.org/external/pubs/ft/scr/2010/cr1065.pdf

[15] International Monetary Fund, "United Arab Emirates: 2009 Article IV Consultation,” Washington DC, 2010. http://www.imf.org/external/pubs/cat/longres.cfm?sk=236 28.0 